\title{
The Journey of Women from Victim to Peace-Maker: Women, Insurgency and Northeast India
}

Dr Piyali Dutta $^{+}$

\section{Abstract}

The sufferings of women in any insurgency movement have been the focus of many women's rights and human rights groups in present times. Studies have demonstrated that women have to suffer pain as mothers, sisters, daughters, caregivers and victims during conflict situation which has till date brought great destruction and despair among them. In the insurgency movements, women continue to struggle as a victim, as combatants, as peace-makers. However, despite being the worst victim, women also play the role of protector of women's rights and human rights. There are many women's organisations in Northeast India like Meira Paibi, Naga Mother's Association, Bodo Women's Justice Forum, which are playing an active role as peace activists. Under this background, the present paper will focus on the role of women's organisations during different situations of insurgency movements in Northeast India. The paper will put special focus on the role of the two women's organisations that is All Bodo Women's Welfare Federation (ABWWF), Bodo Women's Justice Forum (BWJF) in BTC (Bodoland Territorial Council Region) of Assam. BTC is one of the most conflict-affected regions in Assam. Several conflicts have occurred within the region such as ethnic conflicts, fratricidal conflicts, the movement for autonomy and others. The paper will explore the role of these organisations towards protecting the rights of women as well as in bringing peace in the region.

Keywords: Women, Insurgency, Peace Building, Conflict Resolution, Bodoland Territorial Council Region (BTC), Assam, India

\footnotetext{
${ }^{\dagger}$ Assistant Professor, Department of Political Science, Barnagar College, Sorbhog, Assam, India, Email: pdutta00@gmail.com (C) 2018 Dutta. This is an Open Access article distributed under the terms of the Creative Commons Attribution License (http://creativecommons.org/licenses/by/2.0), which permits unrestricted use, distribution, and reproduction in any medium, provided the original work is properly cited.
} 


\section{Introduction}

A variety of conflicts drives the history of postcolonial North East India. This is mainly because the region is based on diverse identities, illegal migration from the border areas and multiple forms of poverty, which have often manifested themselves in brutal and violent ways (Baruah, 1999; 2002; 2005; Bhattacharyya, 2018; Kikon, 2009; McDuie-Ra, 2009a,b). The reasons for the particular conflicts are wide-ranging traversing from separatist movements, to intercommunity, communal and inter-ethnic conflicts (Baruah, 1999; 2002; 2005; Bhattacharyya, 2018; Kikon, 2009; McDuie-Ra, 2009a, b). Violent and vociferous demands by various ethnic groups for independence and new states in the Northeast have been taking place since independence. For instance, Naga insurgency is one of the oldest unresolved armed conflicts demanding for a sovereign Nagalim for which a Framework Agreement was signed between the Government of India (GOI) and the National Socialist Council of Nagaland (Isaac-Muivah) on 3 August 2015 aimed at restoring the 'pride and prestige' of the Nagas (Dutta, 2015; see also, Goswami, 2015; Bhattacharyya,2018; 2019). Similarly, the other states of the North East - Manipur, Assam, Nagaland, Tripura have also been witnessing the large-scale of conflicts because a large number of ethnic communities in these states are engaged in struggle either for the separate state or special status within India Union. The violent nature of these conflicts has affected not only the territorial and political sovereignty of the Indian state but also the life of the people living in this region (Baruah, 1999; 2002; 2005; Bhattacharyya, 2018; Bhattacharyya, 2019; Kikon, 2009; McDuie-Ra, 2009a, b).

Though conflict affects the ordinary civilians, it is the women and children who suffer most in such conflicts. From rape and displacement to the denial of the right to food and medicines, women bear more than their fair share of the burden. (Bhattacharyya, 2018; Chebolu, 2016).Indeed, women and children are exposed to a range of vulnerabilities such as death, torture, sexual violence, disability, hunger, exploitation, trafficking, and so on. (Bhattacharyya, 2017a; 2018). In addition, because of the lack of status within society, women are systematically excluded from decision-making opportunities, they are often stereotyped as victims and their experiences and contributions are virtually ignored in conflict zones (Chebolu, 2016).

However, despite these negative connotations, women should not be viewed only as victims of war. Evidence demonstrates that women often assume the crucial role in cultivating peace within their communities (Bhattacharyya, 2018; Kikon, 2009).

The present paper also tries to reveal how both men and women are affected by the conflicts; focusing on the specific manner in which the existing norms, gender relations influence the shape and the impact of conflict on women. The paper also points out the various challenges faced by women during the peace process.

The paper has been divided into the following parts. It begins with a conceptual framework. Following this, a brief description of the methodology has been deployed. This follows the discussion on different roles played by women in a conflict situation, that is, as-victims, as combatants, as peace-makers, which includes a constructive review of the literature. Following this, it gives a brief discussion on the role of women's organisations in North East India in an armed conflict situation. In this section, a particular emphasis has been laid on two women's organisations - All Bodo Women's Welfare Federation (ABWWF) and Bodo Women Justice Forum (BWJF) of North East India which is currently working on peace negotiation. The final section deals with the conclusion and suggestions.

\section{Conceptual Framework}

The term Insurgency has been used to refer an organised movement which aimed at the overthrow of a constituted government through the use of subversion or armed conflict (Kanwal, 2008: 35). Though there is no single 
definition of the term 'insurgency' as the term has been used by different names like warfare, conflict, revolution (Fall, 1998). Fall (1998: 1-3) 'used the word revolutionary warfare in order to define insurgency. His definition can be stated as RW (Revolutionary Warfare) $=\mathrm{G}$ (Guerrilla Warfare) + P (Political Action). Thus, according to Fall (1998), insurgency means revolutionary warfare which is the result of the application of guerrilla and political system (Fall, 1998). In their article titled Ethnicity, Insurgency, and Civil War, Fearon and Laitin (2001: 2-3) define insurgency as:

Insurgency is a technology of military conflict characterized by small, lightly armed bands practicing guerrilla warfare from rural base areas. As a form of warfare insurgency can be, and has been, harnessed to diverse political agendas, motivations, and grievances. The concept is most closely associated with communist insurgencies fought in Latin America, Asia, and Africa during the Cold War. But the methods can just as well serve Islamic fundamentalists, ethnic nationalists, or "rebels" who focus mainly on the production and sale of coca or diamonds. We certainly agree that ethnic antagonisms, nationalist sentiments, and grievances can motivate rebel fighters and that these may also help their efforts. However, we suspect that these factors are far too common to reliably distinguish the relatively small number of cases where civil war breaks out.

The most prominent theorist of the insurgency was Mao Tse-tung. In his work On Guerrilla Warfare (1937), he stated the fundamental reality that all insurgency is strategically political and directed operationally through multiple lines of effort (only one of which was violence) toward mobilizing a challenge to the state (i.e., a counter-state) sufficient to dominate the correlation of forces (Marks, 2009). In Maoist guerrilla warfare, the insurgents move through three stages, that is, an agitation-propaganda phase, where they would establish bases and prepare the battlefield and the population for the struggle; a defensive phase where they would begin guerrilla warfare operations against the government and terrorism against the resistant population; and finally an offensive phase, where the increasingly influential guerrilla band is created to fight as conventional forces, confronting government forces in direct combat (Collins, 2011). The nature of insurgency movements is not the same everywhere. For example, the North East region of India which is home to a large number of insurgent groups are a reflection of its social, cultural, ethnic and linguistic diversity (see for details in Bhattacharyya, 2018; 2019) Such a process of continuous insurgency has a significant impact on the society where peace restoration becomes utmost important.

Peace is generally defined as a process to end violence (Grewal, 2003). It seeks to prevent, reduce, transform and help people recover from violence in all forms. According to Johan Galtung, there are two aspects of peace, that is, positive peace and negative peace. He defined the absence of conflict as a negative peace, whereas positive peace means structural integration of accomplishing, peace by peaceful means. He has projected positive peace as higher than negative peace because peace does not only define to end violence but it should seek to understand the conditions for preventing violence (Grewal, 2003). Like a Galtung many feminist scholars defined peace as more than the absence of physical violence, insisting that real peace must involve the absence of all forms of violence, including structural and cultural violence and the presence of justice and equality for all. Thus peace means sustainability of the situation which needs positive and creative peacebuilding initiative by the local community (Dutta and Bhuyan, 2008). The peace-building activity follows two parallel paths - one is formal peace negotiations conducted by political leaders and second is many informal activities usually initiated by heterogeneous groups of voluntary organisations to seek peace and influence the formal process. At the 
informal level, it is generally witnessed that peace-building activities are initiated mostly by women at the most crucial periods (Dutta and Bhuyan, 2008). As women are associated with non-violence, most people think that they are natural peacemakers. According to the feminist school of thought, women are more likely to oppose the war, shun violence and inclined toward peacemaking within the community. There are three theoretical models, which are specific to women as a peacemaker, that is as a mother, as a feminist and as an eco-feminist. Among these three roles, the motherly role is the most common (Dutta and Bhuyan, 2008). For example in the case of Northeast India women's organisation like Meira Paibi, Naga Mother's Associations have used their position as mothers to mediate with the armed groups.

\section{Methodology}

The primary purpose of the study is to understand the position of women in a different situation of conflict and their role in conflict resolution in the specific context of two women organisations of Bodoland Territorial Council Region (BTC) region of Assam (see, Figure 1 for an understanding of BTC within the state of Assam). BTC was formed as a result of the long Bodoland Movement which started in the colonial period (the movement started in 1927 when Gurudev Kalicharan Brahma submitted a memorandum to the Simon Commission for separate electorate for the Bodos). The long struggle for separate Bodoland state has been marred with conflicts and bloodshed. On 10th February 2003, GOI signed an MOU (Memorandum of Understanding) with the Bodo Liberation Tigers (BLT), as a result of which BTC was formed. It includes four districts of Assam; they are Kokrajhar, Chirang, Baksa and Udalguri ( Banerjee and Roy, 2010). The BTC has been in operation for 15 years; however, even after its formation, the region continues to be marred with various ethnic conflicts. These conflicts continue to have a significant impact on the lives of civilians and especially women and children.

The data for the present study have been collected from both primary and secondary sources. Primary data have been collected by interviewing the members of the women's organisations. Besides, information was also collected from the locals with an aim to shed light on the present study. The secondary sources were collected from that is, mainly from the books, journals and internet sources.

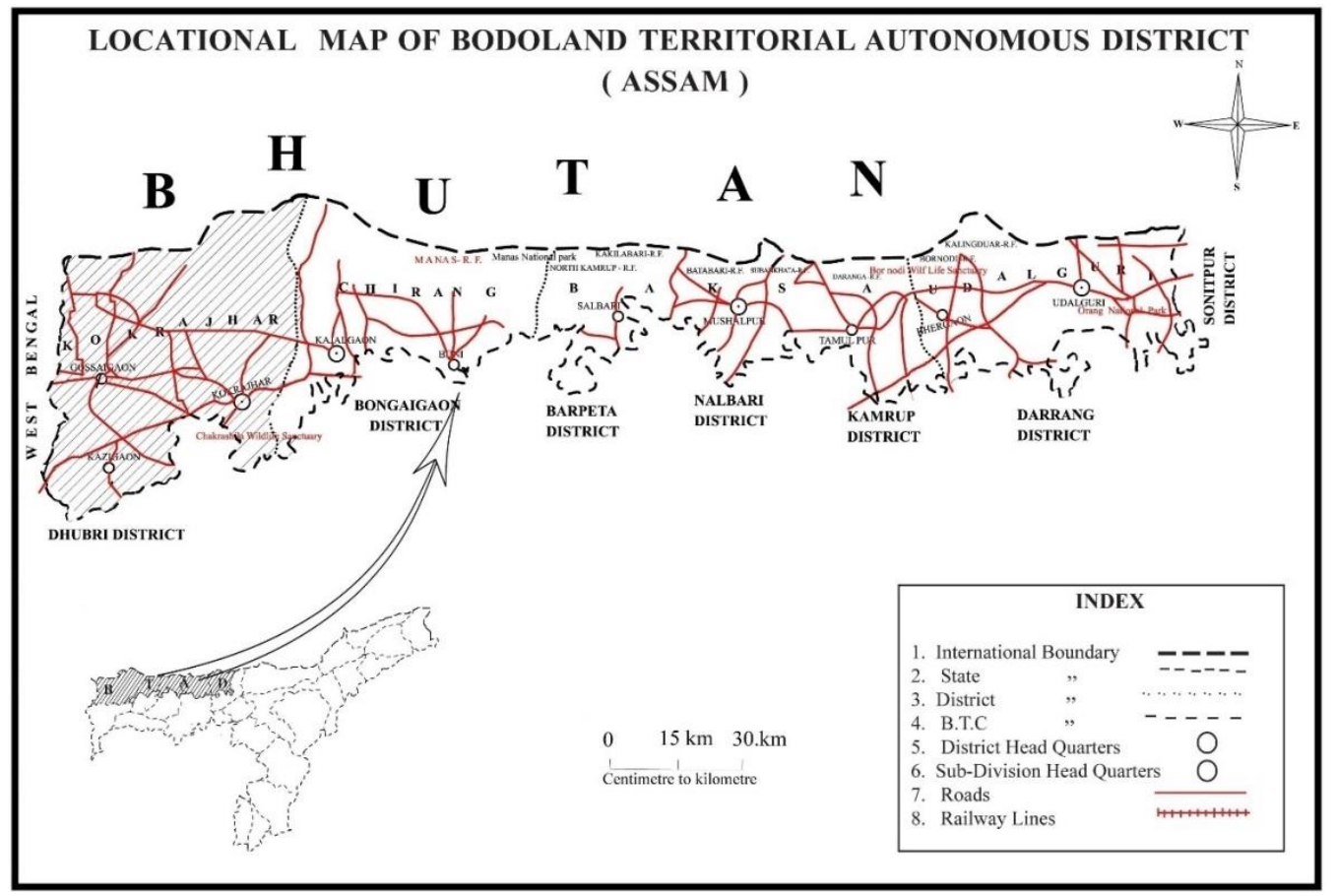

Figure 1: Map of Bodoland Territorial Council Region. Source: Fieldwork 


\section{Women as Victims of Conflicts}

At the launch of the World Population Report in 2010, Thoraya Ahmed Obaid, Executive Director of the United Nations Population Fund (UNFPA) (Eade and Macleod, 2011: 52-53) said:

When women and girls suffer deep discrimination, they are more vulnerable to the worst effects of disaster or war, including the weapon and humiliation of rape, and less likely to contribute to peace-building, which threatens the long-term recovery. If we are serious about preventing conflicts, recovering from war and natural disaster and building lasting peace, we need to empower women, as well as the young and the elderly, to become agents of positive change.

As stated above and elsewhere whenever there are conflicts, women and children have been known to receive the hard end of the stick (Bhattacharyya, 2013). Because of their reproductive capacity, women become symbolic of the community, and of its honour which renders them from vulnerable to all forms of violence and sexual abuse at the hands of those who seek to dishonour their community. Rape and sexual violation of women have been a strategy of war and conflict through the ages. The experience of women in the former Yugoslavia and Rwanda during conflicts in those countries for the first time raised the issue of sexual violence and abuse of women in conflict situations (Bhattacharyya, 2018; Hossain et al. 2014). In modern South Asia also, there is a terrible history of the use of sexual violence against women in times of conflict, from the partition of India in 1947 to the war of liberation in Bangladesh in 1971 (Abeysekera, 2007). In Northeast India and Jammu and Kashmir, there have been several instances where rape has been used as a weapon by the security personnel to dominate the particular community or group (Bhattacharyya, 2013; 2018; Kikon, 2009; Ranjan, 2015). The presence of AFSPA (Armed Forces Special Powers Act) 1958 and 1990, provide excessive power to the concerned authorities, which compromises the fundamental dignity and democratic freedom of the regions (Bhattacharyya, 2018). Bhattacharyya (2018) has demonstrated how AFSPA has become one of the significant causes of violation of women's rights and sexuality in these regions.

The psychological trauma is another impact of conflict on women. Many women in conflict situations face the trauma and tragedy of the loss of loved ones, often mostly male relatives, through death, disappearance, or migration. Evidence suggests that while the consequences of sexual violence are physically, emotionally and psychologically devastating for the women victims, the survivors of such violation have the burden of silently coping with these post trauma stress almost without any form of support (Goswami, 2002; 2015; Kikon, 2009. see, Ahuja, 2003).

Forced displacement is another significant impact of conflict on women. The health of the women is affected by conflict in a number of ways too. In an armed conflict situation, both women and men get injured as direct consequences of widespread violence. However, women's health often faces further burdens due to their social status. The lack of privacy and space in the relief camps has compounded the impact of its and other reproductive health problems for women (Figure 2) (Goswami, 2002; Hossain et al., 2014; see also Pulla, 2016; Bhattacharyya, 2017b). The armed conflict in North-East India has led to the large-scale displacement of people. The research findings suggest that continued ethnic clashes in the BTC region have resulted in mass scale displacement of families. Many of these families are re-settled in relief camps (such as such cramped, makeshift quarters) for many years (Figure 3 ). These camps have little or no access to food, safe drinking water and medicines. The irony is that in camps it is usually the women who have to sustain their families by gathering firewood and ensuring the availability of enough food and clothing.

The findings also reveal that there is a sharp rise in infectious diseases like AIDs. Wherever a woman lives with conflict and upheaval, the threat of HIV/AIDS and its effects are 
multiplied. Evidence suggests that women are more susceptible to infection than men, even some time women are forced by conflict conditions to trade sex for money, food, shelter and any other number of necessities (Rehn and Sirleaf, 2002). Hence, education, protection and access to treatment are essential for people in conflict zones if the rates of infection are to be reduced (Rehn and Sirleaf, 2002). Thus, women in the study area have been the worst sufferers. However, despite being victims, there are groups of women in the study area who have been working rigorously both as combatants and as peacemakers towards combating the insurgency. The next section discusses the role of women as combatants.

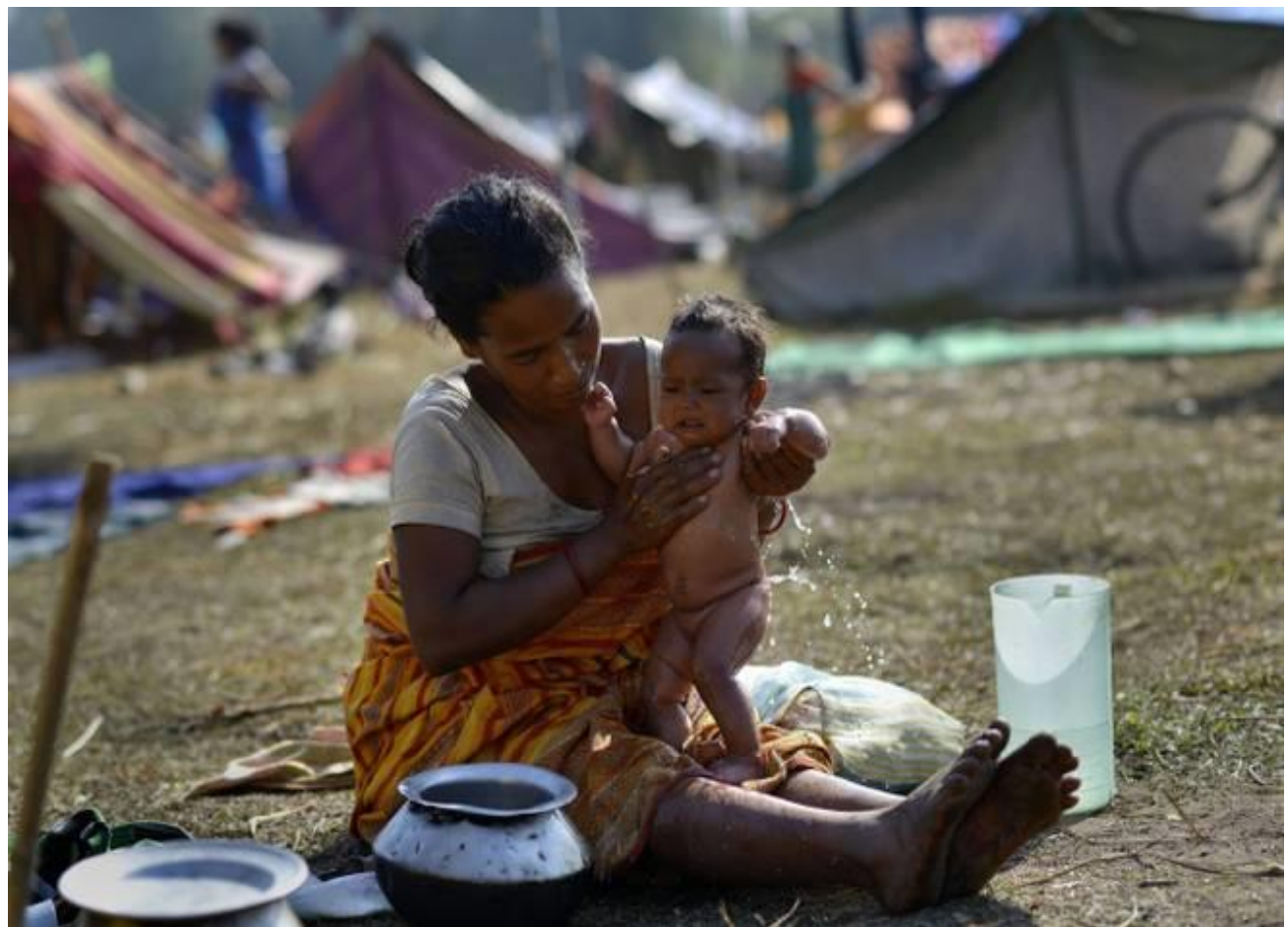

Figure 2: A Bodo Woman with her Newborn Baby at a Relief Camp in Kokrajhar District of Assam, Source: The Hindu, 28/07/2012

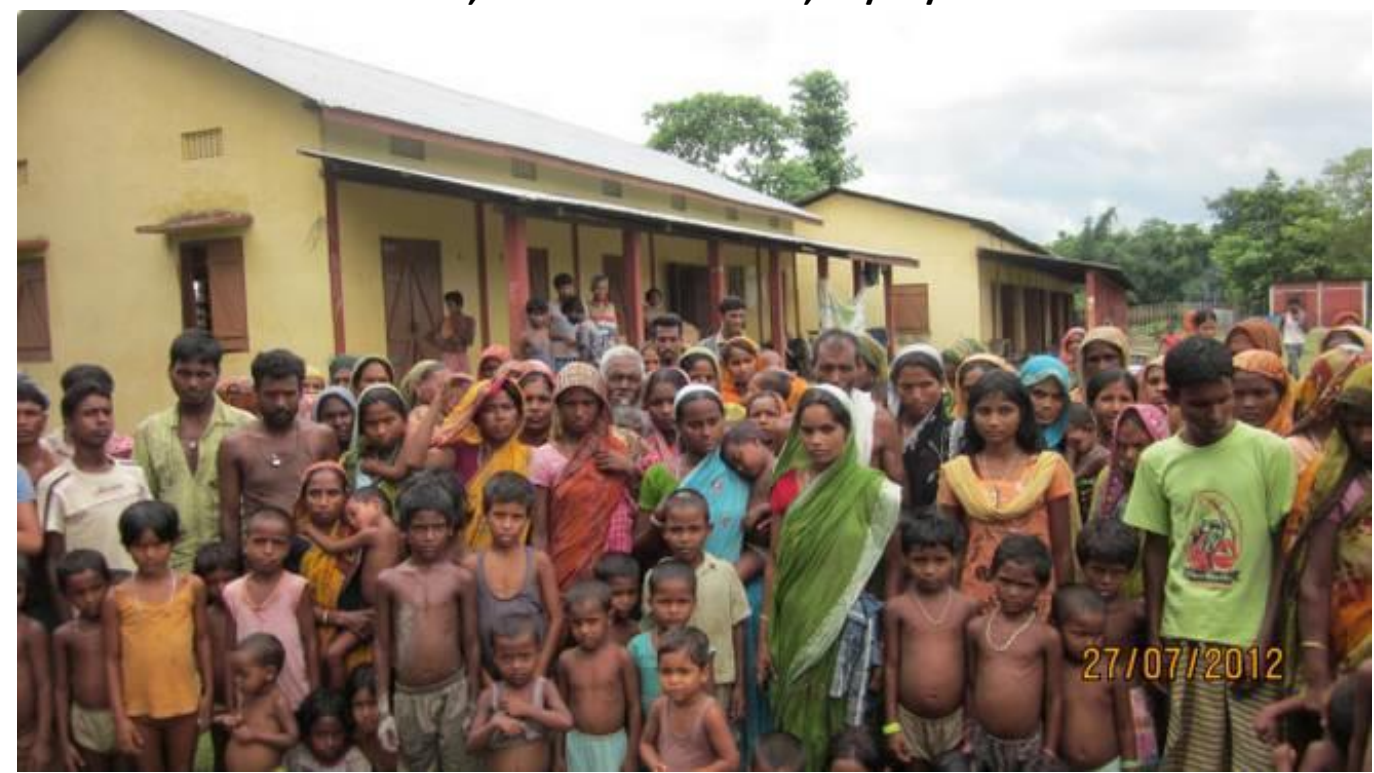

Figure 3. Women and Children at the Badgaon High School Relief Camp in Kokrajhar Source: The Hindu, 28/07/2012

\section{Women as Combatants}

Women's role as combatants is one of the most complex roles played by women in an armed conflict situation. In the pre-colonial period and during the colonial period women have participated in liberation and ethnic movements. However, their support has been 
valued differently than that of men and viewed as a part of infrastructure rather than an agency. This phenomenon is common in the North East. The finding of this research shows that many militant groups have a number of women cadres. These cadres have joined the liberation organisation for specific reasonsranging from their idea of nationalism, ideological appeal and their concern with social and political factors of their region and strategic location. Evidence also suggests that many women joined the cadres because they were unable to bear injustice, harassment and destruction of their homes and people. Many women combatants felt empowered after joining the underground movements and felt that joining such movements have liberated them by bestowing them with some form of responsibility (Shrestha and Thapa, 2007). These women strongly believe joining the insurgency would decrease violence against women. However, observations suggest that violence against women in the BTC region have not reduced, albeit there are no robust data to qualify the claim.

The sexual division of labour in society does not allow women to play the role of the decision maker (Chenoy, 2007). In her book entitled Women, War and Peace in South Asia, Rita Manchanda depicts the picture of the gendered experience of militancy (Manchanda, 2001). In doing so, she found that although women were given equal training when it comes to the implementing it, women are assigned to play only supporting roles and are rarely allowed to handle arms; instead, they become mere informers and help to transport arms and ammunition to one place to another. Next section discusses the role of women as peacemakers.

\section{Women as Peacemakers}

The United Nations Security Council Resolution 1325 passed on the 31st October 2000 recognised the role of women in conflict resolution and peacebuilding. It acknowledged that peace cannot be sustained unless women have an equal and active role in formulating political, economic and social policy and that without women's full participation in peace processes, there can be no justice or sustainable development in the reconstruction of societies. Women become activist and support the peace process in different ways during the conflict, from their homes, through community interactions, and as active negotiators. Scholars argue like that woman are more likely to oppose war as women are often associated with non-violence, and most people think that they are natural peacemakers (Banerjee, 2002; Bhuyan, 2008; Dutta, 2008; Talukdar,2012). Dutta (2008), however, reckons that women are particularly vulnerable during and after conflict but the situation also creates a unique opportunity for women to take part in building new societies from the ruins of the old. Chabra (2005) discusses the role of women in three phases of conflict, that is, prior conflict, during the conflict and after conflict. While emphasising the role of women in the peace process, he posits that women's participation in the peace process should not be viewed only as victims of war and conflict, but as a contributor in the process of peace negotiations, peacebuilding and post-conflict activities.

Similarly, Deepthi Shankar (2008) asserted on strengthening the women as agents of social transformation and not just reduces them to victims of a conflict situation. Women can encourage societies and political groups for achieving sustainable peace by strengthening and promoting activities, local women's organisations and initiatives and by supporting the formation of networks (peace alliances) women can promote cooperation and trust. They can work actively to ward off conflicts by undertaking measures to prevent exclusion and discrimination and can draw attention to other preventive measures through peace-building awareness campaigns (Rehn and Sirleaf, 2002).

Women's role in the conflicts of North East is a clear example of how women are active in civil society as a peace activist. However, in many cases, we found that the role played by women has been marginalised. Women never find their rightful place at the level of the negotiation table. In many social movements in North East 
India, women are utilised, but once the objectives of the struggle are accomplished, their roles are gradually pushed to the periphery. In familiar context, Manchanda (2008: 116) aptly states that: "there remains a huge gap between valuing women as a resource in stopping the violence and respecting them as facilitators in providing a channel of communication, to recognizing that women should be seated at the peace table." Citing an example from Nepal, Manchanda (2008) points that in the history of 20 years of Nepal's Maoist insurgency for the restoration of democracy against the autocratic rule of the King, had propelled thousands of women into politics. Women have been a significant constituency for mobilisation in the Maoist movement and were visible at every level, in the ranks to the Central Committee policymaking level. However, when it came to political arrangements for ceasefire and peacebuilding, there were no women. Hence, according to Manchanda (2008) women should be involved in the post-conflict negotiations for reconstructing polity and society because they are capable of making e a difference (Dutta and Bhuyan, 2008).

\section{Role of Women's Organisations}

There has been a significant proliferation of various types of women's organisations and NGOs in Northeast India. These women's organisations are not only playing an essential role in the empowerment of women but also playing an essential role in protecting the rights of the people. Many times, women groups also back on several issues, including issues of militants. Organisations like Meira Paibis continue to take leading roles in protecting the rights of women in an armed conflict situation in Manipur. As of now the most crucial aim of Meira Paibi is to repeal AFSPA. The Women of Manipur under the banner of Meira Paibi are taking out various protective measures against custodial death, rape, fake encounter committed by the security personnel (Bhattacharyya, 2018; Kikon, 2009; McDuie-Ra, 2009a, b). Like Meira Paibi, Naga Mothers Association and Naga HoHo Women's organisations also take up various forms of activities like protest rally to bring peace in the state. They initiated a campaign on 'Shed No More Blood' and No more violence as an appeal to take up issues peacefully (Chenoy, 2007).

Here, I highlight some experiences from two women's organisations - All Bodo Women's Welfare Federation (ABWWF) and Bodo Women Justice Forum (BWJF) as a peace activist in armed conflict situation of $B T C$ region of Assam (Figure 4 provides a glimpse of my interaction during fieldwork with one of the women's organisation. As noted above, BTC is one of the conflict-affected regions of Assam. The emergence of the conflict situation in the BTC region can be traced back to the Bodoland movement, and this movement has led to several other conflicts in the BTC region. Every stage of the movement has been marred with conflicts and bloodsheds. Besides the movement for separate statehood, the BTC region has also witnessed several other conflicts like ethnic conflicts, fratricidal conflicts, and many more. During the time of BAC (Bodoland Autonomous council) and BTC governments, the region has experienced many times inter-community tensions and violence. For example, an ethnic conflict took place between the Bodos and Muslims in the year 1993, 2008 and 2012. Conflicts also took place between Bodos and Santhals in 1996, 1998. All these conflicts have led to the unprecedented violation of human rights in the BTC region.

In such situations, human rights are threatened either because of the activities of armed opposition or by the armed force deployed by government machinery. Civilians are kidnapped, tortured, displaced and even killed by various insurgent groups. In the name of suppressing insurgency, the Government security forces are again involved in the violation of human rights. Violation of human rights due to harassment and extra-judicial killing of people are common. Many have been tortured on suspicion of being members or having links with insurgent groups. Arrest without warrant, custodial death, murder, 
extra-judicial killings and sexual harassment are common in the region (Bhattacharyya, 2018; Kikon, 2009; McDuie-Ra, 2009a,b). In these such a situations, women's organisation, and NGOs have been are playing an essential role in protecting the rights of the human as well as in bringing peace in the region. Here, I highlight the roles of Women's Welfare Federation (ABWWF) and Bodo Women's Justice Forum (BWJF), both located in BTC.

ABWWF, which was earlier known as AATWW (All Assam Tribal Women's Welfare Federation) was formed on 14 July 1986 by the then President of All Bodo Students Union (ABSU), Mr Upendra Nath Brahma and other prominent leaders like Sansuma Khungur Basumatary, Subhash Basumatary and Darao Dekhrab Narzary. The principal objective of the organisation was to establish equality between men and women while addressing the problems linked to women. In short, the empowerment of women in the region is the central objective of this organisation. Mrs Pramila Rani Brahma, who is currently serving as the Forest Minister, Government of Assam was its first president (Bhuyan, 2008). Thus, the genesis of the organisation can be traced back to the period when the demand for political autonomy for the Bodos mooted by ABSU began in 1980. During this period, it was felt that the Bodo women should not be sidelined in the process as they could play an essential role the overall welfare of the Bodo society. In 1993, the organisation changed its name as ABWWF. The changing of name from AATWWF to ABWWF is mainly because most of the members of the organisation were from the Bodo community.

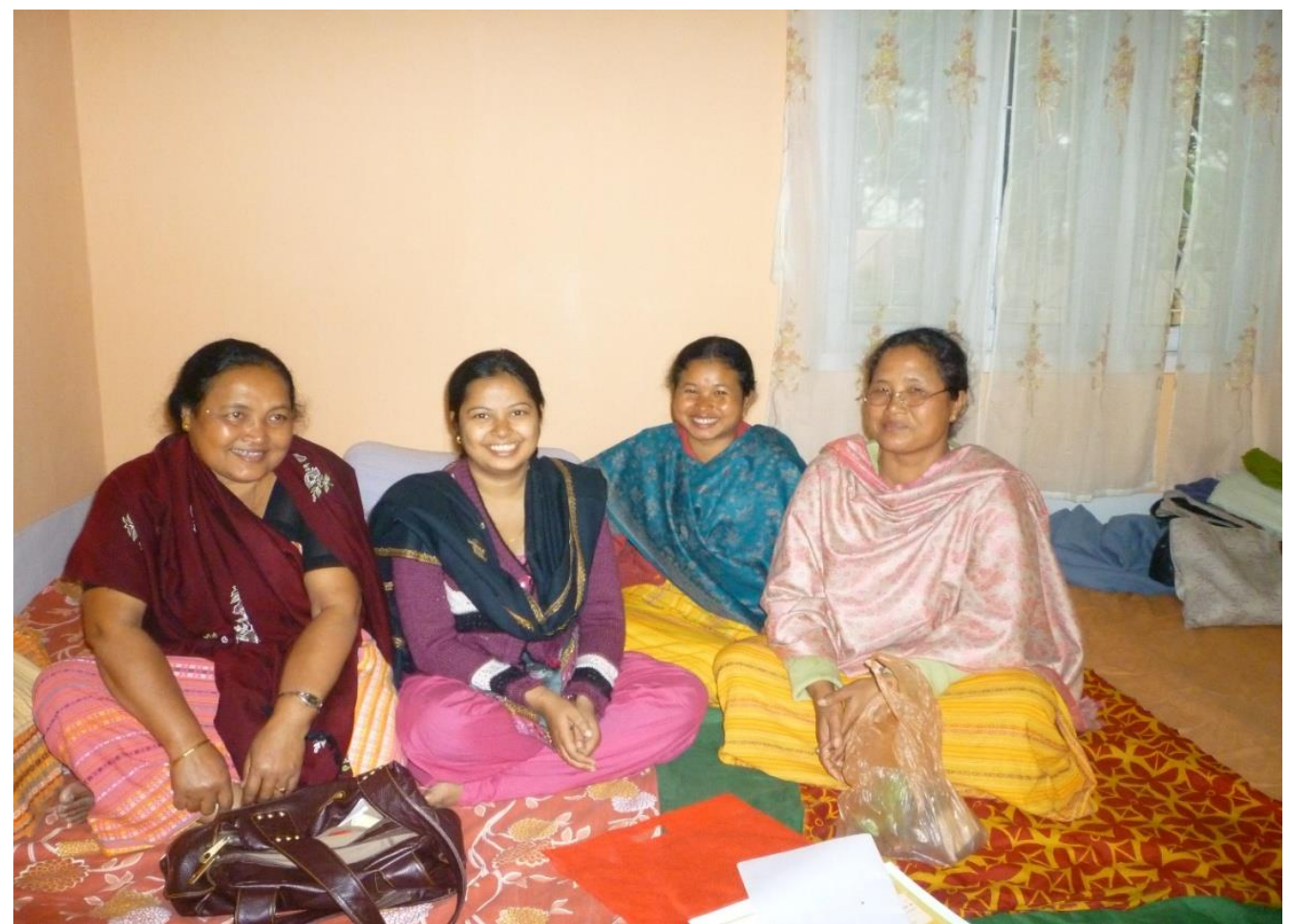

Figure 4: Picture taken during Field Study by the Researcher while Interacting with the Members of the Women's Organisation

ABWWF began as an organisation with an aim to build up the bond of unity among the Bodo community through collective thoughts and action, to stand for equal rights and justice in socio-economic freedom. They started as a wing of the ABSU, and initially, the organisation mainly acted as informants carrying message and letters from one place to another at the instance of the ABSU leaders. However, as the movement became got violent after 1980, their role expanded rapidly. According to Kanan Basumatary (a founder member of the organisation) during the time of ABSU movement the Bodo women and men had faced many severe atrocities on the hands of the security personnel deployed mainly under 
AFSPA. There were many incidents of violation of human rights. During that time ABWWF campaigned for the release of innocent youths from security personnel. ABWWF generally measures like protest march, silent march through the place, gheraoed (encircled) offices of law enforcing and calling for strike and blockade to highlight and resolve the problems of human rights violations, albeit without any adoption of violent/criminal acts such as arson (see Figure 6). From 1989 to 1991, several gheraos were organised by the organisation. In all these gheraos, they compelled the authorities to release those who were arrested from the villages during police raids. According to some members, some of their members lost their lives in these gheraos. For example, on 12th May 1988, Miss Helena Basumatary a 15year-old girl was brutally shot dead by the
Assam Police Task Force while she was along with some women, trying to prevent the arrest of eight innocent Bodo villagers by the Assam Police Task Force. During the movement when the policemen and the army personnel entered villages in search of ABSU activists/activities, they often targeted women. In order to protect women from various atrocities, the village women's were advised to stay in groups during any police and army operation. At the same time, they were asked not to hide any incidents of torture. They also helped the victims to receive compensation from the Government. In January 1988, a number of women of Bhumka area were raped (See Figure 5). It was due to the efforts of ABWWF member the victims of Bhumka rape case received the first instalment though they are yet to receive the second one.

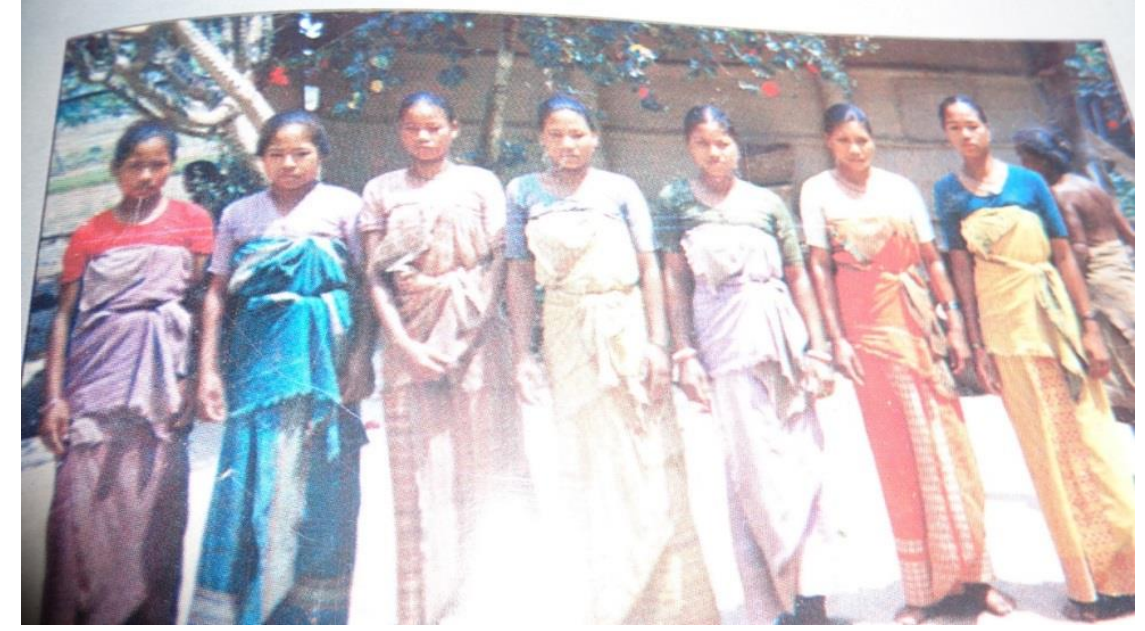

Figure 5: Victims of Bhumka Rape case, Source: Songdan

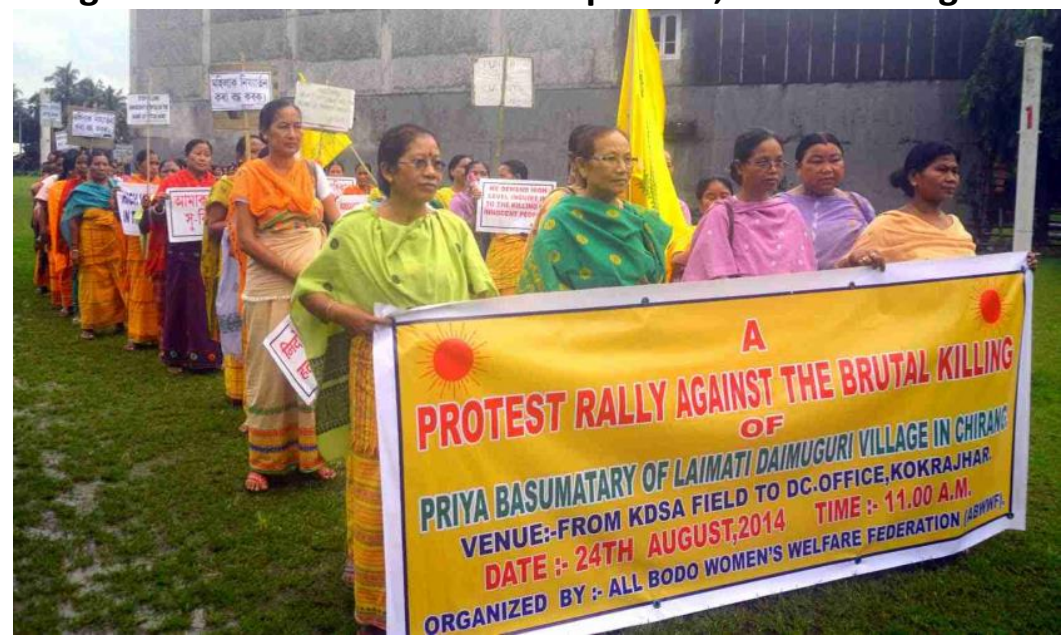

Figure 6: Protest Rally by All Bodo Women's Welfare Federation against the Brutal Killing of a 16-year-old girl, Priya Basumatary by the NDFB(S) militant group. Source: Songdan

ABWWF also organised seminars during conflict Movement in building Bodo nationality; the situations. They were mostly one-day seminar, and the themes were the role of the Bodo role of the Bodo women in the Bodo Movement; the role of the Bodo women in 
social reforms; the importance of formal and social higher education for women, and so on. Such seminars aimed to create awareness among the Bodo people about the movement led by $A B S U$, to create awareness among women about their rights, to encourage women to participate in the social and economic activities.

As part of the peace process, ABWWF has taken up a number of activities aimed at sustainable peace, primary through capacity building, livelihood generation and economic empowerment such as setting up weaving centres, imparting training in the kitchen, gardening, weaving, dairy farming and similar skill-building activities. They also meet the armed groups to resolve the conflict situation in the region. Nevertheless, these women's organisations are rarely invited by the Government for participating in any peace talks. Member of the organisations opines that they are not officially involved in the peace process of the region.

Currently, the organisation has set up many weaving centres at Kokrajhar, Bongaigaon and various other parts of the $B T C$ region with the aim of empowering the women. ABWWF has also established some of Self- Help groups like Jwanglaguri Mahila Samiti, Orchid and many more. The federation also organises seminars, conferences on health issues such as HIV-AIDS, evil practices, witch hunting, dowry deaths. ABWWF observes 4th April of every year as anti-liquor day. ABWWF has also undertaken a mission for adult education for each girl in every household. In the literary field, ABWWF publishes souvenirs, namely, Songdan and Raikhmuthi annually. Many renowned Bodo intellectuals, poets, write on women-related issues in these magazines. The articles mainly discuss the contribution of women to the upliftment of the Bodos, involvement of the Bodo women in politics. Since, 14 August 2003, ABWWF members are running an orphanage named Alayaran at Kokrajhar aimed to look after the victims of the violence. Children who have lost their parents at the hands of security forces or due to fractional killing between the rebel groups are taken in the orphanage (Chaudhuri, 2004; Dutta, 2016).

BWJF is another women's organisation which is working in the BTC region. The organisation was established in 1993 by Miss Anjali Daimary. This organisation aims at the upliftment of the Bodo women making them aware of their rights. The organisation is also a founder member of the Bodo National Convention (BNC) which was formed in 2012 to bring peace to the region. The main aim of the $B N C$ is to reunite the Bodo groups in order to bring peace to the region. According to president Miss Daimary, in a conflict situation it is the women who suffered the most, and in the BTC region, Bodo women faced the brunt of raids by the security personnel due to conflict nature of this region. The organisation continues to consistently oppose the AFSPA using public demonstration, hunger strikes and protest meetings. They have systematically shown the abuse of this law and taken up cases of rape by the armed forces. These findings bear resonance to the findings of Bhattacharyya (2018; Kikon, 2009). To protect women during conflict situation BWJF adopt various mechanisms like protest march, gherao, appealing to the Government through media, etc. For example, on 16th September 2009, together with hundreds of women, Anjali Daimary, initiated bold political demonstration with 'Rape Us' inscribed on their chests and backs against the rape of two young girls in the Udalguri district by the Central Reserve Police Force (CRPF).

Besides, the organisation has also played the role of a mediator between the fractional/militant groups and between the political leaders trying to bring peace in the region. They have initiated appeals, meetings with political leaders as well as the District Administrators regarding the enumeration of the victims. In 2012, during clashes between Bodos and Muslims, representatives from this organisation visited the affected areas and also submitted a memorandum to the District and State administration and tried to secure compensation for the victims. 
Thus, from the above discussion, one can assume that both these organisations are playing essential roles in protecting the rights of women as well as in bringing peace to the region. They had adopted various methods like protest march, seminar, workshop in order to resolve the conflicts in the region. They are not only trying to protect the rights of women but are also playing an important role to empower them socially, politically and economically. However, the roles of these women's organisations are yet to be recognised. After years of struggle, when the agitated groups came into the mainstream society, these women's organisations have failed to receive a chance in the negotiation table. Lack of Government's attention towards the activities of these organisations has also minimised their role as peace initiators. For example, after the formation of BTC when Bodo Liberation Tiger (BLT) formed a new political party and subsequently formed the government, very few women gained the chance to take the leadership role, except for Mrs Pramila Rani Brahma and Mrs KamuliBasumatary. It is indeed sad to note that no other women obtained the chance to contest election from the party. This shows that though these women's organisations have played important roles in different conflict situations when it comes to gaining leading positions, women become invisible. This finding is similar to the observation made by Bhattacharyya (2009) in her research on Assamese middle-class women, where she has argued that although women of Assam actively participated in the All Assam Student's Movement launched in 1979 aimed at tackling the illegal migrant issue; however, the percentage of women accomplishing political leadership is meagre. , Nonetheless, these movements have boosted confidence among many women leaders. For instance, whereas Anjali Daimary independently contested 2016 Assam Assembly election, although she failed to win this election continues to inspire many women to join politics.

\section{Conclusion}

The central aim of this study was to paint the journey of the women's from victim to the role of peacemakers in the BTC area of Assam. The above findings reveal that women might be the worst victims of the conflict but women's organisations continue to play an important role in protecting the rights of women as well as in bringing peace to the region. Indeed, both ABWWF and BWJF are playing essential roles in these aspects. However, both these organisation are confined to their community only do not interfere in the problems faced by the non-Bodo women. This ethnic narrowness can be cited as their limitation. Another limitation of these two organisations is that there is no linkage between these organisations with other women organisations of the North East. Thus, active communication can help these organisations to work in a more constructive way as well as in broadening their outlook. Therefore we can hope that in future, both these organisations can perhaps think beyond their boundaries and work for the broader interest of the society as a whole.

\section{References}

Ahuja, R. (2003). Violence against Women. New Delhi: Rawat Publication.

Abeysekera, S. (2007). The implication of insurgency on women. In A. D. Shrestha, \& R Thapa. (Eds.), The Impact of Armed Conflict on Women in South Asia. (pp. 5258).Regional Centre for Strategic Studies, Colombo: Manohar Publication.

Banerjee, A.C., \& Roy, S. S. (2010). Problems and Prospects of Bodoland. New Delhi: Mittal Publication.

Banerjee, P. (2002). Women's Interventions for Peace in the North-East. Canada: South Asia Partnership.

Baruah, S. (1999). India Against Itself: Politics of Nationality in Assam. Philadelphia, PA: University of Pennsylvania Press.

Baruah, S. (2002). Gulliver's Troubles: State and Militants in Northeast India. Economic and Political Weekly, 37(41), 78-82. 
Baruah, S. (2005). Durable Disorder: Understanding the Politics of Northeast India. UK: Oxford University Press.

Bhuyan, A. (2008). Bodo Women: Peace Makers within the Ethnic Paradigm. In A. Dutta, \& R Bhuyan. (Eds.), Women and Peace Chapters from Northeast India (pp. 3-17). New Delhi: Akansha Publishing House.

Bhattacharyya, R. (2019). Chapter Six: Did India's Partition lead to Segregation of North East India? In A. Ranjan. (Eds.), Partition of India: Postcolonial Legacies. Oxon and New York: Routledge, 105-131

Bhattacharyya, R. (2018). Living with Armed Forces Special Powers Act (AFSPA) as Everyday Life. Geo Journal, 83(1), 31-48, DOI: $10.1007 /$ s10708-016-9752-9

Bhattacharyya, R. (2017a). Sociologies of India's Missing Children. Asian Social Work and Policy Review, 11(1), 90-101, DOI:10.1111/aswp.12116

Bhattacharyya, R. (2017b). The Lhotsampa People of Bhutan: Resilience and Survival. Journal South Asia Research, 37 (1), 113115, DOI: $10.1177 / 0262728016663300$

Bhattacharyya, R. (2013). Criminal law (amendment) act, 2013: Will it ensure women's safety in public spaces?. Journal Space and Culture, India, 1(1), 13-27. doi: 10.20896/saci.v1i1.11

Bhattacharyya, R. (2009). Examining the changing status and role of middle class Assamese women: Lessons from the Lives of University Students. PhD thesis, Newcastle University, UK.

Chaudhuri, S. S. (2004). The Bodo Movement and Women Participation. New Delhi: Mittal Publication.

Chabra, S. (2005). Gender Perspective in Peace Initiatives: Opportunities and Challenges. Retrieved on May 12,2018, from http:// www.eldis.org/fulltest/ womenslinkjo.

Chebolu, D. (2016). Plight of Women War. Imperial Journal of Interdisciplinary Research (IJIR), 2(3), 4145. Retrieved on
May 25, 2018, from

https://www.onlinejournal.in/IJIRV2I3/103 .pdf

Chenoy, M. A. (2007). Resource or symbols? Women and Armed Conflicts in India. In A. D. Shrestha \& R. Thapa. (Eds.). The Impact of Armed Conflicts on Women in South Asia. (pp. 179-189). Regional Centre for Strategic Studies, Colombo: Manohar Publication.

Confortini, C. (2004). Galtung, Violence, and Gender: The Case for a Peace Studies/Feminism Alliance (Paper presented at the annual meeting of the International Studies Association, Le Centre Sheraton Hotel, Montreal, Quebec). Retrieved February, 25, 2018 fromhttp://.kobeu.ac.jp/.../Galtung,\%20Violence\%20and\%2 OGender\%20(Confortini).pdf.

Collins, J. (2011). Understanding War in Afghanistan. Washington, D.C: National Defense University Press.

Concept of Peace: Galtung's view and its implication. (n.d). Retrieved February 25, 2018 from, http://shodhganga.inflibnet.ac.in/bitstrea m/10603/94261/8/08_chapter\%203.pdf

Dutta, A., \& Bhuyan, R. (Eds.). (2008). Women and Peace Chapters from Northeast India. New Delhi: Akansha Publishing House.

Dutta, A. (2008). From Victim to Actors in Peace Building. In S. D. Hazarika. (Eds.). Peace in Dialogue, Universals and Specific: Reflection on Northeast India (pp211-222). New Delhi: Akansha Publishing House.

Dutta, P. (2016). Women and Bodoland Conflict. New Delhi: Akansha Publication.

Dutta, A. R. (2015). The Naga National Struggle, 'Framework Agreement' and the Peace Prospects. Space and Culture, India, 3(2), 514.doi:10.20896/saci.v3i2.151

Eade, D \& Macleod, M. (2011). Women and Armed Conflict: from Victims to Activists. Retrieved February 25, 2018, from http://minorityrights.org/.../download- 
1017-Women-and-armed-conflict-fromvictims-to-ac.

Fall, B. B. (1998). The Theory \& Practice of Insurgency \& Counterinsurgency. Naval War College Review, 51(1). Retrieved February 25, 2018, from, http://digitalcommons.usnwc.edu/nwcrevi ew/vol51/iss1/6

Fearon, J. D, \& Laitin, D. D. (2001). Ethnicity, Insurgency, and Civil War. (Department of Political Science, Stanford University, Stanford) Retrieved July 5, 2018, from http://web.stanford.edu/group/ethnic/wo rkingpapers/apsa011.pdf

Goswami, N. (2015).Indian National Security and Counter-Insurgency: The Use of Force vs Non-Violent Response. Oxon: Routledge.

Goswami, R. (2002). Women in Armed Conflict Situation-The Need for a Human Rights Framework. In A. Mahanta. (Eds.). Human Rights and Women of North East India. (pp 56-67). Dibrugarh University: Centre for Women's Studies.

Grewal, S. B. (2003). Johan Galtung: Positive Peace and Negative Peace. Retrieved July 5, 2018, from http://activeforpeace.org/no/fred/Positive _Negative_Peace.pdf.

Hazarika, D. S. (Eds.). (2008). Peace in Dialogue, Universals and Specific: Reflection on Northeast India. New Delhi: Akansha Publishing House.

Hossain, M., Cathy, Z., \& Watts, C. (2014). Preventing Violence against Women and Girls in Conflict. The Lancet. doi:10.1016/S0140-6736(14)60964-8.

Insurgency: Analytical Framework. (n.d.).Retrieved July 5, 2018, from http://shodhganga.inflibnet.ac.in/bitstrea m/10603/14953/7/07_chapter\%201.pdf.

Kanwal, G. (2008) Sub-Conventional or Low Intensity Conflict?Phraseology and Key Characteristics. Claws Journal, Retrieved February 25, 2018, from http://www.claws.in/images/journals_doc /2043286636_GurmeetKanwal.pdf.
Kikon, D. (2009). The Predicament of Justice: Fifty Years of Armed Force Special Powers Act in India. Contemporary South Asia,271282, doi:10.1080//09584930903108937.

Manchanda. R. (Eds.). (2001). Women, War and Peace in South Asia: Beyond Victimhood to Agency. New Delhi: Sage Publication.

Manchanda. R. (2008). Building Peace: What Difference do Women Make? In A. Dutta \&R Bhuyan. (Eds.). Women and Peace Chapters from Northeast India. (pp109120). New Delhi: Akansha Publishing House.

Marks, T. (2009). Mao Tse-tung and the Search for 21st Century Counterinsurgency. 2 (10). Retrieved on July 5, 2018, fromhttps://ctc.usma.edu/mao-tse-tungand-the-search-for-21st-centurycounterinsurgency/

Mcduie-Ra, D. (2009a). Fifty-year disturbance: The Armed Forces Special Powers Act and exceptionalism in a South Asian periphery. Contemporary South Asia. 17(3), 255270.doi:10.1080/09584930903108911.

McDuie-Ra, D. (2009b). Vision 2020 or re-vision 1958: The Contradictory Politics of Counterinsurgency in India's Regional Engagement. Contemporary South Asia. 17(3), 313330.doi:10.1080/09584930903108994.

Pulla, V. (Ed.). (2016). The Lhotsampa people of Bhutan: Resilience and survival. New York: Palgrave Macmillan.

Ranjan, A. (2015). A gender critique of AFSPA: Security for whom? Social Change, 45(3), 440-457. doi:10.1177/0049085715589471.

Rehn, E. \& Sirleaf, J. E. (2002) Women, War and Peace, The Independent Experts: Assessment on the Impact of Armed Conflict on Women and Women's Role in Peacebuilding. Retrieved July 5, 2018, from https://www.unfpa.org/.../3F71081FF3916 53DC1256C69003170E9-unicef-Women

Shankar, D.(2008).Untappedwomen's agency in conflict resolution and Peace Process. In S. 
D. Hazarika (Eds.). Peace in Dialogue: Universals andSpecifics: Reflection on Northeast India. ( pp127-132). New Delhi: Akansha Publishing House.

Shrestha, D. A. \& Thapa, R. (2007). (Eds). The Impact of Armed Conflicts on Women in South Asia. Regional Centre for Strategic Studies Colombo: Manohar Publication.
Talukdar, B. D. (Ed). (2012). Gender, Peace and Development in Northeast India. Guwahati: DVS Publishers.

\section{Acknowledgements}

The author is grateful to the two anonymous reviewers for their valuable suggestions which helped the author to improve the article. 